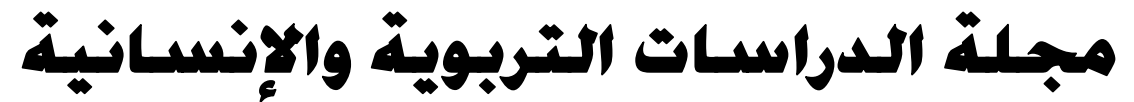 مجلـة كليـة التربيـة - جامعة دمنهور

$$
\text { مجلة علمية- دورية - مصكمة - ربع سنوية }
$$

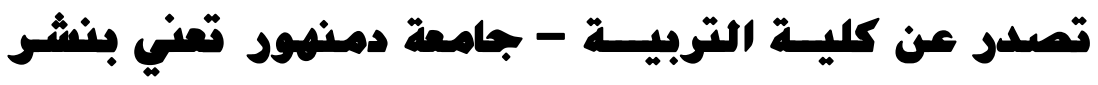 الأبحاث والدراسات في مختف من مجالات الهعرفة التربوية والعلوم النغسية والاجمتهاعية والإنسانية
}

$$
\text { أ.د. أمسل محسيمس مجلس ادارة المجلة بيومس همهران }
$$

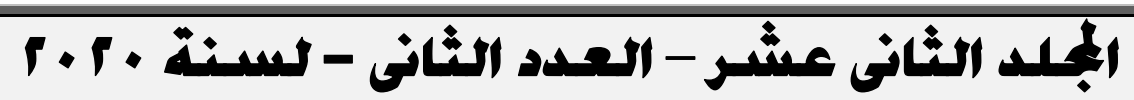


مجلة كلية التربية ـ جامعة دمنهور. المجلد الثانى عشر - العدد الثانى - ل لسنة . r.

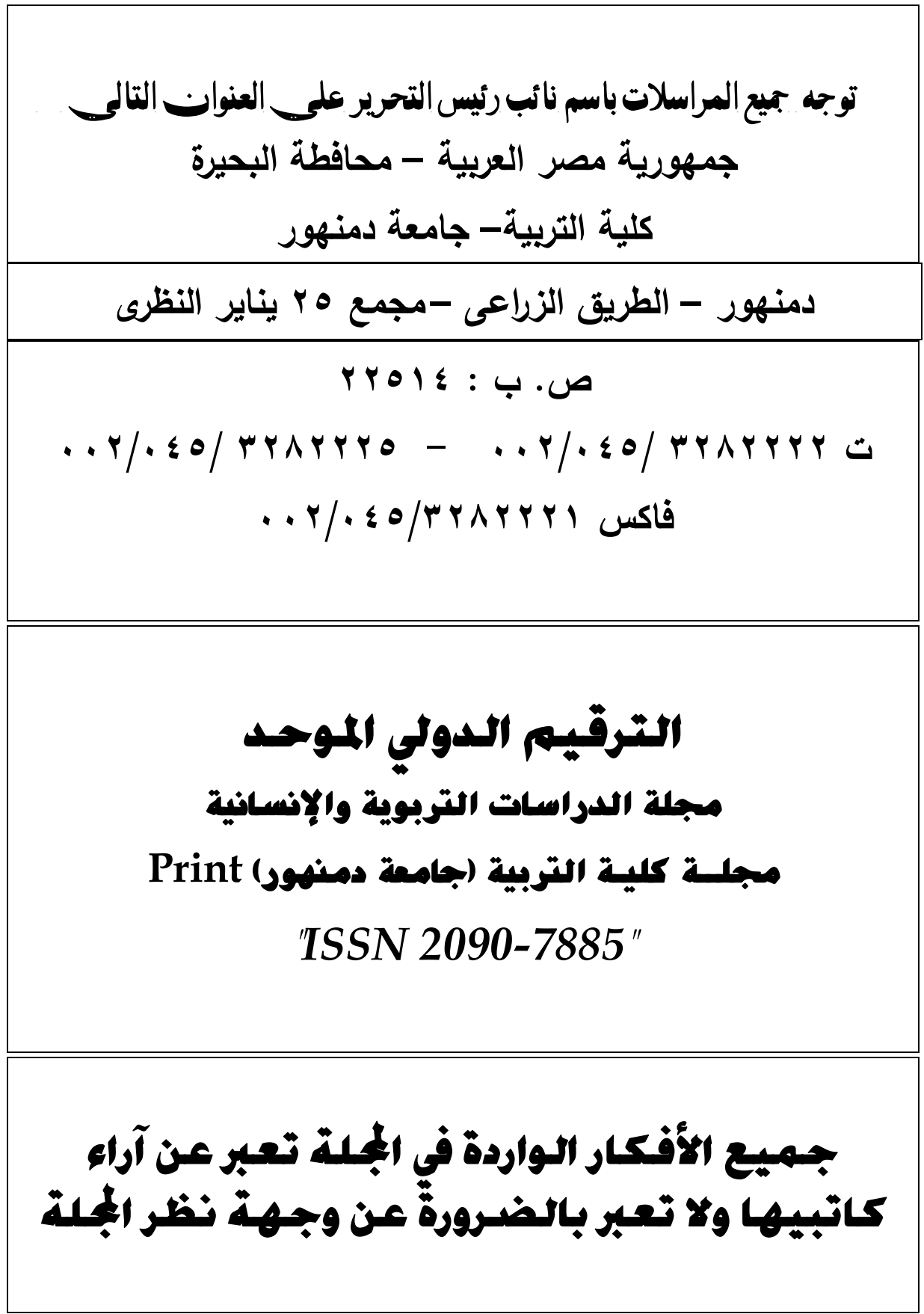





\section{روية الكلبة}

انطلاقًاً مـن روئية جامعة دمنهور تسـى كلية التربيـة إلى الى تحقيق الجـودة والحصـول على الاعتمـاد الأكـاديمي لتحتل

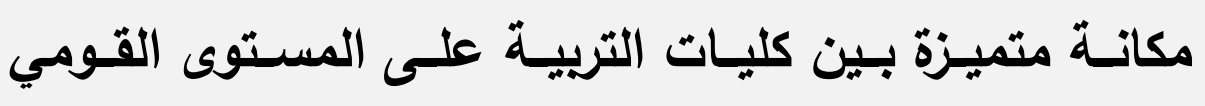
والعالمي

\section{رسالة الكلية}

إعداد المعلمين والكوادر المؤهلة القادرة على تطوير النظم التعليمية والإدارية بالتعليم العام والقنـي، والباحثين القادرين على تطوير المعرفة التريويـة وتوظيفها في حل المشكلات التعليميــة والتربويــة، وتــــريب كافـة العـاملين والقيــادات التريوية، وتوفير الخدمات والاستشارات التريوية المتخصصـة ولتهية

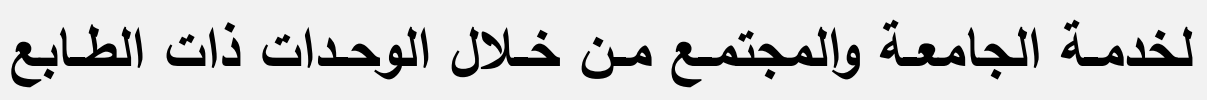
الخاص بها. 